\title{
Efek Antioksidan Jamur Tiram Putih pada Kadar Malondialdehid dan Kepadatan Permukaan Sel Paru Tikus yang Terpapar Asap Rokok
}

\author{
Santun Bhekti Rahimah, ${ }^{1,2}$ Herri S. Sastramihardja, ${ }^{1}$ Trully Detty Sitorus ${ }^{1}$ \\ ${ }^{1}$ Departemen Farmakologi Fakultas Kedokteran Universitas Padjadjaran \\ Rumah Sakit Hasan Sadikin \\ ${ }^{2}$ Bagian Farmakologi Fakultas Kedokteran Universitas Islam Bandung
}

\begin{abstract}
Abstrak
Radikal bebas asap rokok dapat menyebabkan peroksidasi lipid dan perubahan patologis pada sel paru. Hal ini dapat dicegah oleh senyawa yang terkandung dalam jamur tiram putih (Pleurotus ostreatus), antara lain fenol, vitamin C, selenium, dan ergotien. Penelitian bertujuan untuk melihat efek ekstrak jamur tiram putih pada kadar malondialdehid (MDA) dan nilai surface density (S/V) setelah terpapar asap rokok. Metode penelitian menggunakan rancangan acak lengkap dan sebagai pembanding digunakan vitamin E. Dosis ekstrak etanol jamur tiram putih adalah $250 \mathrm{mg} / \mathrm{kgBB}$ dan paparan asap rokok diberikan 30 menit/tikus/hari menggunakan smoking pump. Pada hari ke-11 perlakuan, dilakukan pemeriksaan kadar MDA darah dengan metode thiobarbituric acid assay (TBARS) dan perhitungan nilai S/V paru secara mikroskopis. Penelitian dilakukan pada bulan Juli 2009 di Departemen Farmakologi Klinik Rumah Sakit Hasan Sadikin Bandung. Hasil menunjukkan ekstrak etanol jamur tiram putih mencegah kenaikan kadar MDA darah $(0,4667+0,22295 \mathrm{~nm} / \mathrm{mL})$ dan efeknya sama baik dengan vitamin E $(0,7467+0,24089 \mathrm{~nm} / \mathrm{mL})$. Ekstrak etanol jamur juga mencegah penurunan nilai $\mathrm{S} / \mathrm{V}(0,62283+0,47939)$ dan mempunyai efek yang lebih baik dari vitamin E $(0,54683+0,39832), \mathrm{p}<0,05$. Disimpulkan bahwa ekstrak etanol jamur tiram putih merupakan antioksidan kuat yang lebih baik dibandingkan dengan vitamin $\mathrm{E}$ dalam mencegah kerusakan oksidatif akibat paparan asap rokok. [MKB. 2010;42(4):195-202].
\end{abstract}

Kata kunci: Asap rokok, jamur tiram putih, malondiadehid, nilai S/V, radikal bebas

\section{Antioxidant Effect of Pleurotus ostreatus on Malondialdehyde Level and Surface Density of Rat Lung Cells Exposed to Cigarette Smoke}

\begin{abstract}
Cigarette smoke-free radicals can cause lipid peroxidation and pathological changes in lung cells. This effect could be prevented by highly active metabolite in Pleurotus ostreatus such us fenol, ascorbid acid, selenium, and ergothiene. This study aimed to analyze the effect of the Pleurotus ostreatus extract on the levels of malondialdehyde (MDA) and surface density (S/V) after exposure to cigarette smoke. The research used completed randomized design and $\alpha$-tocopherol was used as control group. The dose of Pleurotus ostreatus ethanol extract was $250 \mathrm{mg} / \mathrm{kg}$ body weight and cigarette smoke exposure was given in 30 minutes/day for 10 days by smoking pump. Malondialdehyde (MDA) level and lung surface density (S/V) were observed on day 11 th. This research was done at Clinical Pharmacology Department, Hasan Sadikin Hospital on July 2009. The result showed that ethanol extract of Pleurotus ostreatus can prevent increasing level of MDA $(0.4667+0.22295 \mathrm{~nm} / \mathrm{mL})$, as good as that of $\alpha$-tocopherol $(0,7467+0,24089 \mathrm{~nm} / \mathrm{mL})$. Ethanol extract also prevented the reduction of lung S/V $(0.62283+0.4793)$ and it's effect was better from $\alpha$-tocopherol $(0.54683 \pm 0.39832), p=<0.05$. In conclusion, our data shows that etanolic extract of Pleurotus ostreatus is a strong antioxidant that have better effect than $\alpha$-tocopherol in preventing oxidative damage of cigarette smoke. [MKB. 2010;42(4):195-202].
\end{abstract}

Key words: Cigarette smoke, free radical, Pleurotus ostreatus, malondyaldehyde, S/V

Korespondensi: Santun Bhekti Rahimah, dr., Mk.Kes, Bagian Farmakologi Fakultas Kedokteran Universitas Islam Bandung, jalan Hariang Banga no. 2 PO.BOX 1357 Bandung 40116, mobile 08562109585, telepon (022) 4203368 pesawat 231, Fax 4231213,e-mail santunikd@yahoo.com 


\section{Pendahuluan}

Estimasi World Health Organization (WHO), penyakit akibat tembakau akan menjadi masalah baru yang melanda dunia setelah human immunodeficiency virus (HIV)/acquired immuno deficiency syndrome (AIDS). ${ }^{1}$ Apabila hal ini tidak dikendalikan secara serius maka pada tahun 2030 akan terdapat 8,3 juta jiwa terenggut oleh penyakit tembakau dan tragisnya $80 \%$ terjadi di negara berkembang. Penggunaan tembakau merupakan salah satu penyebab utama terjadinya sakit di antara penduduk termiskin di Indonesia. Lebih dari $97 \%$ orang yang tidak merokok di Indonesia secara rutin mendapat paparan asap rokok. ${ }^{1}$

Asap rokok mengandung lebih dari 4.700 komponen kimia, di antaranya adalah radikal bebas dan oksidan dalam konsentrasi tinggi. Radikal bebas dari asap rokok berasal dari dua fraksi yang berbeda, yang pertama berasal dari fase tar asap rokok dan yang kedua berasal dari fase gas asap rokok. Radikal bebas yang terdapat dalam tar relatif merupakan radikal bebas yang stabil, antara lain qinon $(\mathrm{Q})$, semiqinon $\left(\mathrm{QH}^{\prime}\right)$, dan hydroqinon $\left(\mathrm{QH}_{2}\right)$. Polimer qinon/hydroqinon $\left(\mathrm{Q} / \mathrm{QH}_{2)}\right.$ bersifat relatif stabil dan dapat mencapai paru. Hal ini memicu terbentuknya radikal bebas lain seperti hidroksil dan peroksinitrit yang dapat merusak komponen-komponen sel paru. Fase gas asap rokok mengandung radikal oksigen dan karbon yang jauh lebih reaktif dibandingkan dengan fase tar. Radikal fase gas tidak timbul dari api rokok, tetapi muncul pada saat oksidasi nitrik oksid (NO) di udara menjadi nitrogen dioksid $\left(\mathrm{NO}_{2}\right)$ yang akan bereaksi dengan spesies reaktif dalam rokok seperti isopren. Nitrogen dioksid $\left(\mathrm{NO}_{2}\right)$ dan oksigen $\left(\mathrm{O}_{2}\right)$ akan segera bereaksi membentuk molekul peroksinitrit (ONOO2) yang sangat reaktif. ${ }^{2-5}$

Organ yang paling berisiko untuk mengalami kerusakan karena asap rokok adalah paru-paru, karena selalu terpapar bahan polutan terus menerus. ${ }^{4}$ Radikal bebas dari asap rokok akan menyebabkan stres oksidatif yang menghasilkan perlukaan langsung dan mengaktivasi mekanisme molekular yang menginisiasi inflamasi pada paru. Kondisi seperti ini apabila dibiarkan akan menyebabkan berbagai keadaan patologis yang dapat diawali dengan terjadinya penurunan kadar antioksidan jaringan, peroksidase lipid, oksidasi protein, dan deoxyribonucleic acid (DNA) yang menyebabkan perubahan patologis pada sel paru. Proses ini berperan penting dalam patogenesis berbagai penyakit paru seperti penyakit paru obstuktif kronik (PPOK) dan karsinoma paru. ${ }^{2-5}$

Peroksidasi lipid merupakan suatu reaksi oksidasi berantai yang juga menghasilkan radikal bebas sehingga mencetuskan peroksidasi lebih lanjut. Reaksi peroksidasi ini menyebabkan rantai asam lemak pada membran sel terputus menjadi berbagai senyawa antara lain malondialdehid (MDA). ${ }^{6}$ Oksidasi protein dan peningkatan sel-sel inflamasi pada paru akan meningkatkan aktivitas enzim proteolisis dan menghambat aktivasi enzim antiproteolisis sehingga alveolus kehilangan integritas dan elastisitasnya. Paru dengan alveolus melebar menyebabkan kepadatan permukaan paru atau surface density (S/V) menurun sehingga morfologi dan struktur alveolus berubah. Hal ini mengakibatkan terganggunya proses pertukaran oksigen dan karbondioksida di paru. ${ }^{3,5-8}$

Mekanisme pertahanan terhadap radikal bebas yang dapat terdiri dari enzim dan molekul antioksidan dimiliki oleh tubuh termasuk sel-sel paru. ${ }^{2}$ Stres oksidatif yang disebabkan asap rokok akan menyebabkan ketidakseimbangan antara oksidan dan antioksidan sehinga kadar antioksidan endogen termasuk vitamin E, vitamin C, tripeptide gluthatione (GSH; $\gamma$-L-glutamyl-Lcysteinylglycine), dan lain-lain akan menurun. ${ }^{7.8}$ Hal ini menyebabkan tubuh kita memerlukan antioksidan eksogen untuk membantu mengurangi efek tersebut, salah satunya dengan menggunakan tumbuhan yang berkhasiat sebagai antioksidan.

Jamur tiram putih (Pleurotus ostreatus) dapat berfungsi sebagai antioksidan karena mengandung senyawa fenolik, L-ergotien, selenium, dan vitamin $C^{8}{ }^{8}$ Senyawa fenolik dapat menghambat reaksi oksidasi serta mampu bertindak sebagai pereduksi radikal hidroksil, superoksida, dan peroksil. Fenolik juga terbukti mempunyai pengaruh pada proses transkripsi sintesis antioksidan endogen, yaitu glutation. ${ }^{6}$ Berdasarkan pada sifat antioksidan jamur tiram putih tersebut, penelitian ini bertujuan untuk melihat efek ekstrak jamur tiram putih pada kadar MDA darah dan nilai $\mathrm{S} / \mathrm{V}$ paru tikus setelah mendapat paparan asap rokok, dibandingkan dengan vitamin E.

\section{Metode}

Rancangan penelitian adalah rancangan acak 
lengkap. Besar sampel ditentukan menggunakan rumus Gomez, dengan jumlah perlakuan 4 didapatkan hasil akhir pengulangan (r) adalah 4,5 (dibulatkan 5), ditambah 10\% sebagai antisipasi drop out, sehingga menjadi 5,5 dibulatkan menjadi 6. Dua puluh empat ekor tikus dibagi dalam empat kelompok secara acak $(n=6)$ masingmasing dengan perlakuan berikut: Kelompok I, berlaku sebagai kontrol negatif, diberi akuabides 3 $\mathrm{mL} /$ tikus/hari. Kelompok II, adalah kontrol positif, dipaparkan asap rokok selama 30 menit/ hari selama 10 hari dengan menggunakan smoking pump. Kelompok III adalah kelompok perlakuan yang dipaparkan asap rokok selama 30 menit/hari selama 10 hari dan diberi ekstrak jamur tiram putih dosis $250 \mathrm{mg} / \mathrm{kg}$ BB. Kelompok IV adalah kelompok pembanding, yang dipaparkan asap rokok selama 30 menit/hari selama 10 hari dan diberi vitamin E $30 \mathrm{mg} / \mathrm{kgBB}$. Pada hari ke-11 perlakuan, tikus diambil darahnya dari jantung sebanyak $3 \mathrm{~mL}$ untuk dilakukan pemeriksaan peroksidasi lipid dengan mengukur kadar MDA menggunakan metode thiobarbituric acid assay (TBARs). Malondialdehid dapat digunakan untuk membuktikan terjadinya deteriorasi oksidatif pada suatu substrat dan salah satu tes yang paling sering digunakan untuk mengetahui kadar MDA adalah thiobarbituric acid assay (TBARS). Thiobarbituric acid assay adalah pemeriksaan MDA yang relatif mudah dikerjakan dan cepat. ${ }^{9,10}$ Thiobarbituric acid (TBA) ditambahkan ke dalam sampel sehingga terbentuk formasi kompleks MDA-TBA menghasilkan warna merah yang dapat diperiksa dengan spektrofotometri $(\lambda \max =$ 532-535 nm). Pemeriksaan harus dilakukan pada $\mathrm{pH}$ rendah dan kenaikan temperatur yang halus. Pemeriksaan ini dapat dilakukan secara in vivo dan juga dengan model sistem lipid seperti mikrosom atau liposom. Pemeriksaan lain yang lebih akurat untuk mengukur MDA dengan menggunakan TBA HPLC (high performance liquid chromatography) assay akan tetapi metode ini lebih mahal dan prosedurnya lebih rumit. ${ }^{10}$

Tikus dikorbankan dan diambil jaringan parunya untuk pemeriksaan histopatologis setelah pengambilan sampel darah untuk pengukuran MDA. Jaringan paru difiksasi dan diwarnai dengan pewarnaan hematoksilin eosin.

Sel paru yang terpapar rokok juga dapat mengalami perubahan histologis yang bervariasi, antara lain: penebalan septum alveolar sampai fibrosis, pelebaran dinding alveolus, makrofag yang sitoplasmanya banyak mengandung debu cokelat (smoker's macrophages) atau besi dan infiltrasi limfosit. ${ }^{4,5}$ Pelebaran dinding alveolus disebabkan oleh hilangnya integritas alveolus (alveolar attachment) serta destruksi parenkim. Proses ini diawali oleh oksidasi protein yang meningkatkan aktivitas enzim proteolisis dan menginaktivasi enzim antiproteolisis sehingga terjadi ketidakseimbangan pada enzim tersebut. Oksidasi protein juga menyebabkan kerusakan serat elastin pada jaringan interstitial sehingga alveolus kehilangan kemampuan elastisitasnya. ${ }^{4 \cdot 5}$ Pelebaran dinding alveolus ini merupakan salah satu indikator objektif yang dapat dinilai secara mikroskopis dengan mengukur nilai kepadatan permukaan paru (surface density) atau nilai S/V.

Perubahan-perubahan sel paru tersebut pada akhirnya dapat menimbulkan penyakit yang berkaitan dengan merokok, dapat dibagi menjadi penyakit obstruktif (emfisema, bronkitis kronik) dan penyakit restriktif atau interstisial (fibrosis idiopatik interstitial, deskuamatif pneumonia interstitial, dan bronkiolitis respiratori). ${ }^{11}$

Preparat yang sudah diwarnai diamati dengan mikroskop cahaya merk Olympus, untuk dilihat diameter alveolus pada setiap preparat dengan pembesaran 40x dan 100x. Diameter yang melebar lebih dari kelompok kontrol negatif menandakan adanya sel patologis. Setiap ekor tikus dibuat 1 preparat sehingga satu kelompok memiliki 6 preparat. Setiap preparat terdiri dari 5 sampai 7 sayatan. Dari setiap preparat diambil 2 sayatan secara acak. Dari setiap sayatan diambil 3 lapang pandang pada area tertentu. Pada setiap area tertentu dihitung diameter 5 alveolus secara acak. Jumlah alveolus dihitung dari setiap tikus adalah $5 \times 3 \times 2=30$ alveolus, sehingga total jumlah alveolus yang dihitung adalah $30 \times 6 \times 4=720$ alveolus. Kepadatan permukaan paru dilihat dengan membandingkan parameter surface (S) dengan volume $(\mathrm{V})$.

$$
\mathrm{S} / \mathrm{V}=\pi / 4 \times \mathrm{P} / \mathrm{A}
$$

Keterangan:

$\mathrm{S} / \mathrm{V}=$ surface/volume atau kepadatan permukaan per volume

$\mathrm{P}=$ keliling dari rata- rata alveolus pada area tertentu

$=\underline{\text { luas area tertentu } \mathrm{x} \text { keliling rata-rata alveolus }}$

$$
=\frac{400 \times \pi \mathrm{d}}{\pi \mathrm{r}^{2}}
$$

$\mathrm{A}=$ Luas area tertentu

$$
=400 \mu \mathrm{m}^{2}
$$


Analisis statistik menggunakan analisis varians (ANOVA), dilanjutkan dengan uji post hoc Bonferroni dan dipertegas dengan uji jarak berganda dari Duncan dengan taraf kepercayaan $95 \% \quad(p<0,05)$ dianggap bermakna, dengan menggunakan SPSS 17.

\section{Hasil}

Berikut ini adalah hasil pengukuran MDA darah tikus menggunakan spektrofotometri dengan panjang gelombang $(\lambda \max ) 532-535 \mathrm{~nm}$.

Tabel 1 menunjukkan bahwa kelompok yang memiliki kadar MDA terkecil adalah kelompok I dengan rata-rata $0,03200 \pm 0,123 \mathrm{nmol} / \mathrm{mL}$, diikuti oleh kelompok III $(0,04667 \pm 0,223 \mathrm{nmol} / \mathrm{mL})$ dan kelompok IV $(0,07667 \pm 0,241 \mathrm{nmol} / \mathrm{mL})$. Nilai MDA terbesar adalah kelompok II dengan kadar rata-rata $0,1912 \pm 0,120 \mathrm{nmol} / \mathrm{mL}$.

Pada Tabel 2 terlihat bahwa dengan uji post hoc Bonferroni, kadar MDA pada kelompok I berbeda bermakna dengan kelompok II $(\mathrm{p}=0,002)$, sedangkan antara kelompok III dan IV tidak ada perbedaan bermakna $(p>0,005)$. Kadar MDA pada kelompok II mempunyai perbedaan bermakna dengan semua kelompok $(\mathrm{p}<0,005)$. Kadar MDA pada kelompok III berbeda bermakna dengan kelompok II $(p=0,004)$. Hasil uji Bonferroni, dipertegas dengan uji jarak berganda Duncan.

Uji jarak berganda Duncan memperlihatkan bahwa kelompok I, III, dan IV berada pada subset yang sama. Hal ini berarti pemberian ekstrak etanol jamur tiram putih dan vitamin E pada tikus yang dipaparkan asap rokok tidak menyebabkan peningkatan MDA yang berarti. Kelompok II berada pada subset yang berbeda, karena memiliki kadar MDA terbesar dan berbeda secara bermakna dibandingkan dengan ketiga kelompok lainnya.

Perhitungan nilai $(\mathrm{S} / \mathrm{V})$ hasil pemeriksaan histologis jaringan paru tikus diperlihatkan pada Tabel 3. Kelompok dengan S/V yang paling kecil adalah kelompok II $(0,33483 \pm 0,027)$, sedangkan kelompok I mempunyai nilai $\mathrm{S} / \mathrm{V}$ paling besar $(0,77067 \pm 0,053)$, diikuti oleh kelompok III $(0,62283 \pm 0,048)$ dan IV $(0,54683 \pm 0,04)$.

Pada Tabel 4 terlihat bahwa semua kelompok mempunyai perbedaan bermakna dibandingkan

Tabel 1 Kadar Rata-Rata MDADarah Tikus

\begin{tabular}{lccc}
\hline Kelompok & n (tikus) & Mean $(\mathbf{n m o l} / \mathbf{m L})$ & SD \\
\hline Negatif & 6 & 0,03200 & 0,012394 \\
Positif & 6 & 0,19117 & 0,120310 \\
Perlakuan & 6 & 0,04667 & 0,022295 \\
Pembanding & 6 & 0,07467 & 0,024089 \\
\hline
\end{tabular}

Keterangan:

Kelompok I : Kontrol negatif (akuabides $3 \mathrm{~mL} /$ hari)

Kelompok II : Kontrol positif (asap rokok 30 menit/hari)

Kelompok III : Kelompok perlakuan (asap rokok 30 menit/hari dan ekstrak etanol jamur tiram putih $250 \mathrm{mg} / \mathrm{kgBB}$ )

Kelompok IV: Kelompok pembanding (asap rokok 30 menit/hari dan vitamin E 30mg/kgBB)

Tabel 2 Uji Post Hoc Bonferroni Kadar MDA Darah Tikus

\begin{tabular}{lllccc}
\hline \multirow{2}{*}{ Kelompok } & & $\begin{array}{c}\text { Mean } \\
\text { Difference }\end{array}$ & Std. Error & Sig \\
\hline Bonferroni & Negatif & Positif & $-0,159167^{*}$ & 0,036177 & 0,002 \\
& Perlakuan & $-0,014667$ & 0,036177 & 1,000 \\
& Pembanding & $-0,042667$ & 0,036177 & 1,000 \\
& Positif & Negatif & $0,159167^{*}$ & 0,036177 & 0,002 \\
& Perlakuan & $0,144500^{*}$ & 0,036177 & 0,004 \\
& Perlakuan & Pembanding & $0,116500^{*}$ & 0,036177 & 0,026 \\
& Negatif & 0,014667 & 0,036177 & 1,000 \\
& Positif & $-0,144500^{*}$ & 0,036177 & 0,004 \\
& Pembanding & Negatif & 0,028000 & 0,036177 & 1,000 \\
& & Positif & $-0,116500^{*}$ & 0,036177 & 1,000 \\
& & Perlakuan & 0,028000 & 0,036177 & 0,026 \\
& & & & 1,000 \\
\hline
\end{tabular}

*- Mean difference bermakna pada level 0,5 
Tabel 3 Nilai S/V Paru Tikus

\begin{tabular}{lccc}
\hline Kelompok & N & Mean & SD \\
\hline Negatif & 6 & 0,77067 & 0,053324 \\
Positif & 6 & 0,33483 & 0,027404 \\
Perlakuan & 6 & 0,62283 & 0,047939 \\
Pembanding & 6 & 0,54683 & 0,039832 \\
\hline
\end{tabular}

dengan kelompok lain. Kelompok I mempunyai perbedaan yang bermakna dengan kelompok II, III, dan IV. Hasil uji jarak berganda Duncan, menunjukkan bahwa masing-masing kelompok berada pada empat subset yang berbeda, berarti keempatnya memiliki perbedaan bermakna untuk nilai S/V. Subset 1 terdiri dari kelompok dengan nilai S/V paling kecil, yaitu kelompok II dengan nilai rata-rata sebesar 0,33483 . Subset 2 adalah kelompok IV $(0,54683)$. Subset 3 adalah kelompok III $(0,622683)$. Subset 4 diisi oleh kelompok I $(0,77067)$.

Gambar A adalah kelompok kontrol negatif; tampak jaringan alveolus paru yang mempunyai diameter dan kepadatan permukaan paru normal. Gambar B adalah kelompok kontrol positif; tampak alveolusnya melebar dan kepadatan permukaan paru menurun dibandingkan dengan kelompok kontrol negatif. Gambar $\mathrm{C}$ adalah kelompok perlakuan; tampak jaringan paru yang membaik dibandingkan dengan kelompok kontrol positif, diameter alveolus tampak mengecil dan kepadatan permukaan paru mendekati normal. Gambar D adalah kelompok pembanding; tampak jaringan paru yang mulai membaik pula dengan diameter alveolus yang tidak terlalu melebar dan kepadatan permukaan paru yang tidak terlalu berkurang.

\section{Pembahasan}

Kadar MDA yang paling rendah pada kelompok kontrol negatif disebabkan karena tidak ada faktor pencetus apapun yang dapat menyebabkan peningkatan MDA, sedangkan kenaikan kadar MDA yang paling bermakna pada kelompok kontrol positif disebabkan stres oksidatif oleh asap rokok tidak diimbangi dengan pemberian antioksidan eksogen sehingga peroksidasi lipid tetap berlanjut. Pada kelompok perlakuan serta kelompok pembanding, keduanya diberi zat yang mempunyai khasiat antioksidan sehingga tidak ada peningkatan kadar MDA yang bermakna. Ekstrak jamur tiram putih dosis $250 \mathrm{mg} / \mathrm{kgBB}$ mempunyai efek antioksidan yang besar karena mengandung zat-zat yang mempunyai khasiat antioksidan seperti senyawa fenol, ergotien, vitamin C, selenium, dan beta karoten. Senyawa fenol merupakan komponen dengan aktivitas antioksidan yang paling besar pada jamur tiram putih. Aktivitas antioksidan fenolik terutama disebabkan oleh kemampuannya sebagai agen pereduksi donor hidrogen dan singlet oxygen quencher, selain komponen ini juga mempunyai efek metal chelation yang potensial., Antioksidan fenolik juga mempengaruhi faktor traskripsi pada proses sintesis $\mathrm{GSH}^{2,12,14-16}$

Tabel 4 Uji Post Hoc Bonferroni Nilai S/V Paru Tikus

\begin{tabular}{|c|c|c|c|c|c|}
\hline \multicolumn{3}{|c|}{ Kelompok } & \multirow{2}{*}{$\begin{array}{c}\text { Mean } \\
\text { Difference }\end{array}$} & \multirow{2}{*}{$\begin{array}{c}\text { Std. Error } \\
0,024965\end{array}$} & \multirow{2}{*}{$\frac{\text { Sig }}{0,000}$} \\
\hline Bonferroni & Negatif & Positif & & & \\
\hline & & Perlakuan & $0,147833^{*}$ & 0,024965 & 0,000 \\
\hline & & Pembanding & $0,223833 *$ & 0,024965 & 0,000 \\
\hline & Positif & Negatif & $-0,435833^{*}$ & 0,024965 & 0,000 \\
\hline & & Perlakuan & $-0,288000^{*}$ & 0,024965 & 0,000 \\
\hline & & Pembanding & $-0,212000^{*}$ & 0,024965 & 0,000 \\
\hline & Perlakuan & Negatif & $-0,147833^{*}$ & 0,024965 & 0,000 \\
\hline & & Positif & $0,288000 *$ & 0,024965 & 0,000 \\
\hline & & Pembanding & $0,076000 *$ & 0,024965 & 0,038 \\
\hline & Pembanding & Negatif & $-0,223833^{*}$ & 0,024965 & 0,000 \\
\hline & & Positif & $0,212000^{*}$ & 0,024965 & 0,000 \\
\hline & & Perlakuan & $-0,076000 *$ & 0,024965 & 0,038 \\
\hline
\end{tabular}




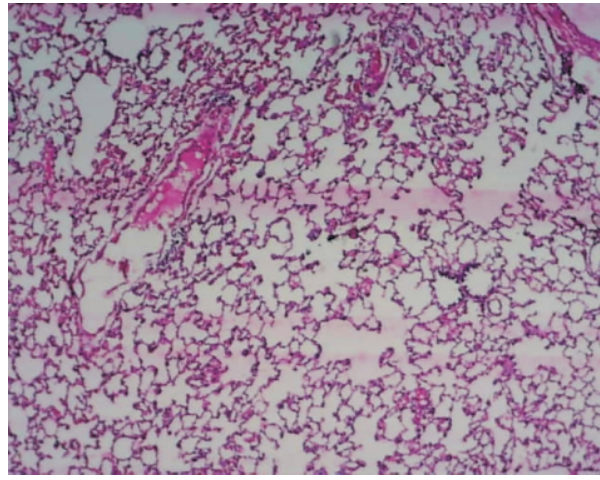

A

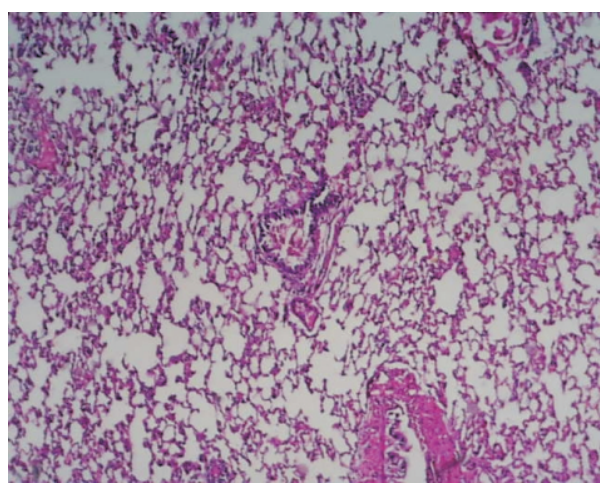

$\mathrm{C}$

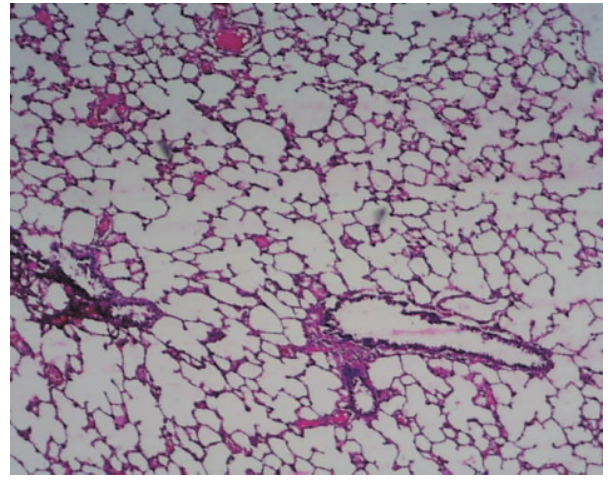

B

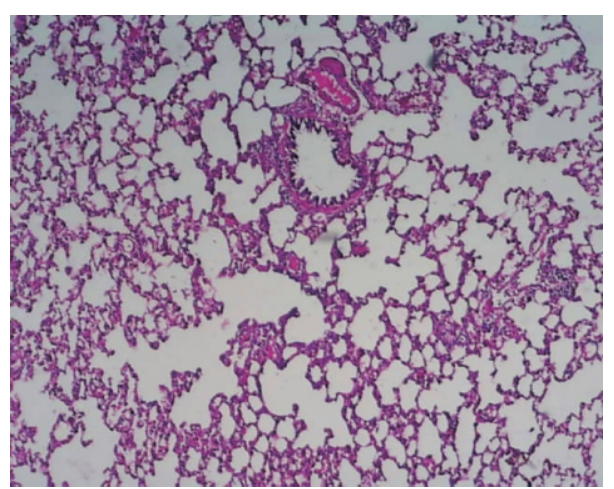

D

\section{Gambar Histopatologis Paru pada Pembesaran 40x}

Kemampuan antioksidan jamur tiram putih sebagai antioksidan eksogen dengan kandungan fenoliknya, mampu mencegah kenaikan kadar MDA pada tikus yang dipapar asap rokok selama 30 menit/hari.

Ekstrak jamur tiram putih pada dosis 250 $\mathrm{mg} / \mathrm{kgBB}$ dibandingkan dengan vitamin $\mathrm{E}$ dosis $30 \mathrm{mg} / \mathrm{kgBB}$, mempunyai aktivitas antioksidan yang sama baiknya dalam mencegah kenaikan kadar MDA akibat paparan asap rokok selama 30 menit/hari selama 10 hari. Vitamin E merupakan antioksidan kuat yang larut dalam lemak, mengandung satu zat aktif, yaitu $\alpha$-tokoferol dengan satu mekanisme kerja dalam melawan radikal bebas, sedangkan jamur tiram putih mengandung banyak zat yang mempunyai efek antioksidan selain fenol dengan mekanisme kerja yang lebih bervariasi. ${ }^{17}$ Berdasarkan hal tersebut diperkirakan ekstrak etanol jamur tiram putih memberikan efek antioksidan yang lebih besar dibandingkan dengan vitamin $\mathrm{E}$ dalam mencegah kenaikan kadar MDA karena paparan asap rokok, akan tetapi ternyata hasil uji statistik menyatakan bahwa keduanya memberikan hasil yang sama baik.

Kondisi ini dapat disebabkan beberapa hal sebagai berikut:1) penelitian ini menggunakan ekstrak dari fruiting body, kemungkinan terdapat zat lain yang dapat mempunyai efek menetralisir efek antioksidan dari senyawa fenolik dan yang lainnya, sedangkan pada vitamin E hanya terdiri dari satu zat aktif saja, 2) Pemeriksaan MDA diambil dari sampel darah tikus, berarti berasal dari kerusakan sistemik selain dari sel paru, kemungkinan antioksidan mempunyai spefisikasi yang lebih tinggi pada organ-organ tertentu.

Paru normal yang tidak mendapatkan paparan asap rokok mempunyai kepadatan permukaan paru yang besar, artinya alveolus mempunyai diameter yang relatif normal. Kelompok kontrol positif mempunyai nilai $\mathrm{S} / \mathrm{V}$ yang paling menurun, karena rata-rata diameter alveolusnya melebar apabila dibandingkan dengan kontrol negatif. Sel paru yang terpapar rokok dapat mengalami perubahan patologis seperti pelebaran dinding alveolus. Pelebaran dinding alveolus ini diawali oleh oksidasi protein yang menyebabkan ketidakseimbangan enzim proteolisis dan anti- 
proteolisis pada paru sehingga kehilangan integritas (alveolus atthacment) dan kemampuan elastisitasnya., ${ }^{2,5}$

Nilai S/V yang menurun pada kelompok kontrol positif membuktikan bahwa asap rokok dapat menyebabkan stres oksidatif pada makromolekul tubuh seperti lipid dan protein yang mengubah morfologi sel. Kelompok perlakuan menunjukkan kenaikan nilai S/V dibandingkan dengan kelompok kontrol positif walaupun tidak sama dengan kelompok kontrol negatif. Hasil ini menggambarkan bahwa penurunan $\mathrm{S} / \mathrm{V}$ pada kelompok yang mendapat jamur ini tidak terlalu bermakna. Jamur adalah antioksidan kuat yang mengandung berbagai zat antioksidan, terutama senyawa fenol. Efek radikal bebas yang timbul dari paparan asap rokok dapat diimbangi dengan pemberian ekstrak etanol jamur tiram putih yang mempunyai sifat antioksidan kuat, berarti terdapat keseimbangan antara oksidan dan prooksidan.

Kelompok pembanding juga memperlihatkan adanya penurunan $\mathrm{S} / \mathrm{V}$ yang tidak terlalu besar dibandingkan dengan kontrol positif, akan tetapi secara statistik nilainya masih lebih rendah dibandingkan dengan nilai $\mathrm{S} / \mathrm{V}$ dari kelompok perlakuan. Nilai ini menggambarkan bahwa untuk parameter $\mathrm{S} / \mathrm{V}$, ekstrak etanol jamur tiram putih mempunyai kemampuan untuk mencegah penurunan nilai $\mathrm{S} / \mathrm{V}$ lebih baik daripada vitamin E. Hal ini kemungkinan besar disebabkan oleh antara lain: 1) Ekstrak etanol jamur tiram putih mengandung lebih dari satu zat aktif yang bersifat antioksidan dan kemungkinan terjadi efek sinergi yang kuat, sehingga hasilnya lebih baik dari vitamin E yang hanya mempunyai satu zat aktif, yaitu $\alpha$-tokoferol. 2) Senyawa fenol membantu proses transkripsi pada sintesis GSH, sehingga selain sebagai antioksidan eksogen juga meningkatkan sintesis antioksidan endogen, yang pada akhirnya semakin meningkatkan sistem pertahanan paru terhadap stres oksidatif. ${ }^{4}$ Hasil penelitian ini yang telah diuji secara statistik menunjukkan bahwa ekstrak etanol jamur tiram putih terbukti mempunyai efek antioksidan yang kuat dalam melawan kerusakan oksidatif akibat asap rokok. ${ }^{2,11,14 .}$

Disimpulkan bahwa pemberian ekstrak etanol jamur tiram putih dosis $250 \mathrm{mg} / \mathrm{kgBB}$ dapat mencegah kenaikan kadar MDA darah tikus yang dipaparkan asap rokok dan efeknya sama baik dengan vitamin E dosis $30 \mathrm{mg} / \mathrm{kgBB}$. Pemberian ekstrak etanol jamur tiram putih dosis 250 $\mathrm{mg} / \mathrm{kgBB}$ juga mencegah penurunan nilai $\mathrm{S} / \mathrm{V}$ sel paru tikus yang mendapat pemaparan asap rokok dan efeknya lebih besar daripada vitamin $\mathrm{E}$ dosis $30 \mathrm{mg} / \mathrm{kgBB}$.

\section{Daftar Pustaka}

1. Barber S, Ahsan A, Adioetomo SM, Setyonaluri D. Tobacco economics in Indonesia. Paris: International Unio Against Tuberculosis and Lung Disease; 2008.

2. Misra A, Chattopadhyay R, Banerjee S, Chattopadhyay DJ, Chatterjee IB. Black tea prevents cigarette smoke-induced oxidative damage of protein in guinea pigs. Nutrient Interactions and Toxicity. 2003;133:2622-8.

3. Van deer VH, Postma SD, Timens W, Ten Hacken NHT. Acute effect of cigarette smoke on inflammation and oxidative strees: occasional review. J Thorax. 2003. (diunduh 9 Juli 2009). Tersedia dari: http://thorax.bmj.com/cgi/content/ full/ $/ 58 / 21 / 135$

4. Baneerje S, Chattopadhayay R, Gosh A, Koley H, Panda K, Roy S, dkk. Chatellular and molecular mechanism of cigarette smoke-induced lung damage and prevent. J Inflammation. 2008;5: 21.

5. Amin K, Jansson EA, Lofdahl CG, Venge P. Relationship between inflammatory cell and structural changes in the lungs of asymptomatic and never smoker: a biopsy study, airway biology. J Thorax. 2003. (diunduh 9 Juli 2009). Tersedia dari: http://thorax.bmj.com/cgi/content/full/58/ 21/135.

6. Khotimah S. Pengaruh pemberian ekstrak jinten hitam (Nigella sativa) terhadap kadar GSH paru dan hepar tikus Wistar yang dipapar asap rokok. JBP. 2008;8(2):55-60.

7. Ueta E, Tadokoro Y, Yamamoto T, Yamane C, Suzuki E, Nanba E, dkk. The effect of cigarette smoke exposure and ascorbic acid intake on gene expression of antioxidant enzymes and other related enzymes in the livers and lungs of Shionogi rats with osteogenic disorders. Toxicological Sciences. 2003;73:339-47.

8. Jayakumara T, Ramesha E, Geraldine P. Antioxidant activity of the oyster mushroom, Pleurotus ostreatus, on $\mathrm{CCl}_{4}$ - induced liver injury in rats. J Food Chemical Toxicol. 2006;44:198996.

9. McMullen R. Techniques to measure lipid peroxidation, Cosmetiscope, New York Society of Cosmetic Chemists 2008;14(3) (diunduh 9 Juli 2009). Tersedia dari: http:// www.nyscc.org.

10. Lykkesfeldt J. Determination of malondialdehyde as dithiobarbituric ction comparison with ultraviolet visible spectrophotometry, Clin Chem. 
2001;47(9):1725-27.

11. Kumar V, Abbas AK, Fausto N. Robbins and Cotran pathologic basic of disease. Philadelphia: Elsevier Saunder; 2005.

12. Tjandra YA. Global Youth Tobacco Survey (Repeat) Indonesia. Jakarta:UI Press; 2006.

13. Van deer VH, Postma SD, Timens W, Ten Hacken NHT. Acute effect of cigarette smoke on inflammation and oxidative strees: occasional review. J Thorax. 2003 (diunduh 9 Juli 2009). Tersedia dari: http://thorax.bmj.com/cgi/content/ full/58/21/135.

14. Zhang J, Jiang S, Watson RR. Antioxidant supple- mentation prevents oxidation and inflammatory responses induced by sidestream cigarette smoke in old mice. Environm Health Perspectives. 2001; 109:1006-9.

15. Papas AM. Antioxidant status, diet, nutrition, and health. Bota Raton Florida: CRC Prees; 1999.

16. Kahkonen MP, Hopia AI, Vucorela HJ, Rauha JP. Antioxidant activity of plant extracts containing phenolic compounds. J Agric Food Chem. 1999; 47: 3954-62.

17. Bruno RS, Traber MG. Cigarettes smoke alter human vitamin E requirements, recents advances in nutritional sciences. J Nutrit. 2005;135:671-4. 